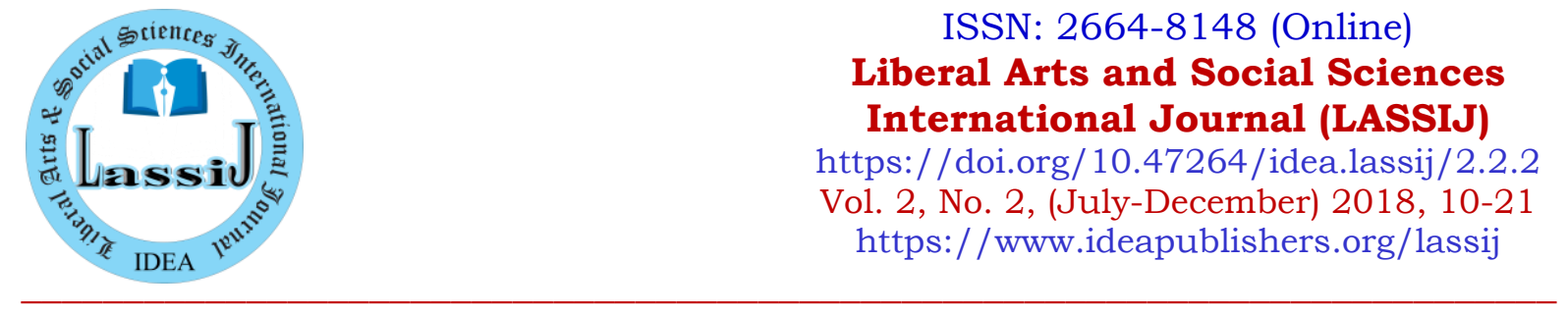

\title{
Kargil Operation and its Effects on the Civil-Military Relations in Pakistan
}

\author{
Ashfaq U. Rehman ${ }^{1}$, Shughla Ashfaq ${ }^{2 *}$ and Taj Muharram Khan ${ }^{3}$
}

1. Department of Political Science, Faculty of Social Sciences, Women University Swabi, Swabi, Pakistan.

2. Department of Politics \& International Relations, International Islamic University Islamabad, Pakistan.

3. Department of Political Science, Faculty of Social Sciences, University of Peshawar, Peshawar, Pakistan.

\begin{abstract}
This paper aims to analyse the reasons of strained civil-military relations between the Army under General Pervaiz Musharraf as Chief of Army Staff and the civilian government under the premiership of Nawaz Sharif. A mixed method approach has been adopted for collection of primary and secondary data for this descriptive, theoretical, and qualitative study. The analysis shows that the relations between the two institutions i.e., the civilian government and the military were deteriorated due to an ill-fated Kargil war launched by the then Army Chief solely on his own decision. The war under the guise of Kashmiri mujahedeen movement became an unpleasant event for Pakistan in the international community. The situation compelled the elected government to declare withdrawal of the para-military forces unilaterally thus causing further damages in terms of human and material losses. The military, opposition parties and other groups in the country blamed the civilian government for this failure. Therefore, the post Kargil war developments became a major source of contention between civil and military leadership. The events and reasons leading to the removal of Army Chief, dismissal of elected government and dissolution of national and provincial assemblies have been critically analysed in this study.
\end{abstract}

Keywords: Democracy, Kargil War, Civil-Military Relations, Military Coup, Kashmir, Dismissal of Government

\section{Introduction}

The decade of 1990s is very crucial in terms of civil-military relations for the elected governments and democratic consolidation. It is due to strained relations of the political leadership with other state institutions in the post Ziaul Haq period. The lack of national leadership, political training, foresightedness, and tolerance to accommodate each other's demands by the opposition parties contributed further in weakening of political system (Rehman, Khan \& Khan, 2017; Khan \& Rehman, 2018). The paper analyses the relations between the Army Chief General Pervaiz Musharraf and government of Prime Minister Nawaz Sharif vis-à-vis the Kargil Operation. The Army, though operating from the backdrop during early years of 1990s became more active in deciding state affairs during General Musharraf period. It expanded its role to an extent that the military expeditions across the border was launched without consulting the prime minister and other services chiefs. No doubt, there was 
a lack of preparation on the diplomatic front due to which the political leadership could not justify the expedition in the international community.

The lack of coordination among state institutions and the international pressure compelled the political leadership to request the US for an early end of the war. However, there was a precondition from the US to unilaterally withdraw the troops across Line of Control (LOC). Nonetheless, signing of this agreement by Prime Minister Nawaz Sharif became the cause of disagreement between the civil-military leadership. The opposition also added fuel to the situation by declaring that through Washington Accord, Nawaz Sharif lost on the table what the military had won in the battlefield. The poor performance of Nawaz Sharif government, involving army in civilian administration and especially the post Kargil developments turned the political scenario against the government. Moreover, an attempt of Nawaz Sharif to remove the General Pervaiz Musharraf from his office before due date became an immediate reason for retaliation of the Army. The elected government was dismissed, the Constitution was suspended, and the General Pervaiz Musharraf assumed role of the Chief Executive of the country in October 1999.

\section{Literature Review and Background}

The military, especially in developing world assumes that the political leaders, the institutional framework of elected government and the overall political culture is inadequate to address the needs of the country (Huntington, 1968). Moreover, the military tags itself as the only patriot institution in the country. Likewise, the military regards itself as one of the strongest organization which takes the responsibility to decide what the best is for the people and that only they have the capability to defend the country both internally and externally. This is believed based on their organizational characteristics, institutional strength, and resources. Janowitz examines that among the characteristics of military include internal cohesion and organisational unity along with means and professionalism being the distinction that provide military a greater ability to deal with political instability in comparison to other state institutions (Janowitz, 1977). Constitution being a supreme law for governing a country is either abrogated or suspended when the military decides to intervene in the politics. This is followed by drastic initiatives such as suspension of the constitution, dismantling elected government, dissolving parliament, and restricting judiciary's power terming these steps to be in the national interest.

The existing literature on military's taking control of power especially in the third world countries suggests that the military does so because of ill-governance, corruption of the civilian government, anarchy and deteriorating capacity of the civilians to run the government for the betterment of the people. The literature also examines the reasons and types of withdrawals which are decided upon by the military itself. No other institution can make the military to step down and allow the people to choose their rulers (Finer, 1975). The theorists have opined that military takes the advantage of the absence of strong political leadership and failure of institutions based on their personal assumption. In some cases, the military is invited by the politicians to takeover when power struggle among them reaches to the climax (Brooker, 2000). The political theorists argue that there is always a vacuum in the governing system which, in case of the developing countries, is filled by the military as a saviour of the country. In some cases, the countries which have suffered from the coups have a strategic placement geographically that allows military to takeover and rescue the system. Other similarity is the 
colonialism as most of these countries had been colonies and have been in the making of democracies (Nordlinger, 1977).

During his first term in office as Prime Minister, Nawaz Sharif had remained submissive to the then Army Chief, General Asif Nawaz Janjua. In his second term, however, he enjoyed strong majority in the parliament and seemed more confident. The president was his handpicked figure, Supreme Court was dealt as less effective and he was having a strong hold on parliamentary members of PML-N. When differences emerged between the Army Chief and the Prime Minister, General Jahangir Karamat was aware of his weak support from the Corps Commanders. Therefore, instead of confronting, he sought early retirement and resigned three months before the due date. Although resigned, his refusal Army Chief to clarify his statement ${ }^{1}$ was non-compliance to the orders of prime minister and an extra constitutional act. It confirmed that the Army Chief considered himself superior to prime minister thus publicly undermined the supremacy of the elected government as an institution.

The prime minister Nawaz Shairf appointed General Pervaiz Musharraf as Army Chief who superseded one Pashtun and another Punjabi general. ${ }^{2}$ Moreover, the senior most general, Ali Kuli Khan was expected to be appointed as Chairman Joint Chiefs of Staff Committee (JCSC) to redress the injustice done to him. ${ }^{3}$ But later in his meeting with Shahbaz Sharif and Chaudhury Nisar Ali Khan, General (Retd.) Jahangir Karamat expressed that his colleagues like General Ali Kuli Khan had insisted him to take over the government and not to resign. However, he had decided to follow the Constitution and thus resigned from his post. Due to these reports, Prime Minister Nawaz Sharif decided not to appoint General Ali Kuli Khan as Chairman JCSC. As a result, General Ali Kuli Khan resigned and later denied these reports also (Aziz, 2009). The newly appointed Army Chief held a meeting with General Jahangir Karamat and insisted that it was the suggestion of all corps commanders to discuss the need of National Security Council (NSC) with Prime Minister. General Pervaiz Musharraf further assured him of no hurry on his part for assuming the office of Army Chief and expressed willingness to convey it to the Corps Commanders. However, General Jahangir Karamat refused to take any retaliatory action against the government and advised General Pervaiz Musharraf to take his charge (Shah, 2016).

The prime minister thought that a Muhajir Army Chief, commanding a Punjabi-Pashtun dominated military establishment would be in a weak position to take over the elected government (Rizvi, 1999). The prime minister was taking this strategy in terms of Biradari System like the politicians and feudal lords who often use it as a policy. His assumption was wrong because the military is not a democracy where majority exerts pressure on the leadership (Shah, 2016). The Army Chief, in the hierarchical structure, is the powerful head. The earlier experiences show that the subordinates have always obeyed the chief even if he had resorted to an unconstitutional act for his survival. Moreover, the Army Chief represents the corporate interests of the military as an institution. Therefore, the successor chief always pursues existing policies irrespective of his ethnic or provincial background. Therefore, the perception of Nawaz Sharif that the military institution can be weakened as he had done with the judiciary proved damaging for his own self. However, initially Nawaz Sharif and General Pervaiz Musharraf were on the same page. The military was exercising special powers conferred on them under Anti-terrorism Act (ATA) for curbing the extremists responsible for bad law and order. The military was granted extensive powers for conducting investigations and setting up parallel military courts, decisions of which could not be challenged in any civil court (Daily Dawn, 
November 21, 1998). However, the Supreme Court later declared these military courts unconstitutional (Daily Dawn, February 17, 1999).

Nawaz Sharif, to strengthen the civilian, set up, inducted the military into various government institutions for curbing corruption and improvement in the economic health of the country (Daily Dawn, November 21, 1998). Almost, thirty-five thousand junior commissioned and commissioned officers were appointed in Water \& Power Development Authority (WAPDA). A Lt. General was appointed as the Chairman and a Maj. General as a Vice-Chairman of WAPDA. The serving Brigadiers were made in-charge of eight transmission companies. The military was assigned administrative responsibilities of Karachi Water and Sewerage Board (KWSB), and the National Database and Registration Authority (NADRA). Education Department of Punjab was also assigned to the military to conduct monitoring of their daily duties, posting and transfers. Serving military officers were assigned key posts in civilian departments like intelligence agencies, police services, civil bureaucracy, Karachi Electric Supply Company (KESC) and Cholistan Development Authority. Nawaz Sharif allowed this intrusion and considered General Pervaiz Musharraf as the same pliable Army Chief as Bhutto had considered General Ziaul Haq. However, both the prime ministers were mistaken. The situation changed when General Pervaiz Musharraf issued an order in March 1999 declaring that in future, the military officers deputed in WAPDA would be conducting negotiations with the independent power producers. A list of the WAPDA defaulters was also issued including members of PML-N which embarrassed the prime minister in public.

\section{Research Methodology}

A mixed method approach has been adopted for the conduction of this exploratory research. The study is descriptive, theoretical, and qualitative in nature and the data collection for this study has included both primary and secondary sources. The primary source is an important and valuable source to conduct and analyse the research. The primary sources for this research included the newspapers and archives of official documents of the government, the legislatures, and the judiciary. Newspapers are consulted for analysing news items and public statement of the government officials and public office holders. The semi-structured interviews of prominent figures are also conducted. A discussion guide i.e., an interview schedule has been developed for conducting the key informant interviews and obtaining knowledge from concerned quarters. As the topic is related to the recent past, the researcher contacted experts known for their balanced views on the questions under consideration. Interviews are conducted with politicians, advocates of the superior courts, retired military personnel and those who are either involved in the processes or are witnesses to the problem under investigation. The theoretical and historical aspects of the study are dealt with through secondary resources, such as reference books, journal articles, newspaper articles, relevant theses, and reports. The secondary sources included both published and unpublished material on the subject. Analysis of statements, books, journals, magazines, gazetteers, newspapers, and government records is also made for the purpose.

\section{Discussion and Findings}

\subsection{Kargil Operation and Turmoil in Civil-Military Relations}

Role of Nawaz Sharif in the Kargil Operation became one of the major reasons of confrontation 
with General Pervaiz Musharraf. The controversy about the approval of the government to the military for undertaking the Kargil operation still exists. According to General Pervaiz Musharraf, Nawaz Sharif was informed of the military action in Kargil (Musharraf, 2006). However, Nawaz Sharif showed ignorance of the move (Waraich, 2006). Due to its disastrous consequences for Pakistan, no one was ready to take the responsibility for this misadventure. This controversy led to a verbal duel between Nawaz Sharif and General Pervaiz Musharraf, that whether the prime minister was fully briefed on launching of the operation in advance or not (Aziz, 2009).

In March 1999, General Pervaiz Musharraf and his team briefed Nawaz Sharif about the situation and therefore two sessions were held on 12-13 March 1999. The briefing highlighted the intensifying activity of Mujahideen inside Kashmir particularly in Kargil-Daras sector. However, it was not revealed that any new operation of Pakistani troops was going on to cross the LoC and that only Stinger Missiles will be provided to Mujahideen. In response to the concerns of Lt. General (Rtd.) Abdul Majid Malik, the Minister for Kashmir Affairs and Sartaj Aziz, Foreign Minister of Pakistan; General Pervaiz Musharraf responded that we cannot take responsibility of Mujahideen activity inside Kashmir. He further stated that we know Indians, and they will seriously negotiate on Kashmir only in such intense pressure (Aziz, 2009). With the proofs of ID cards and diaries of Pakistan Army, India confirmed that the attack was not conducted by the freedom fighters and that the regular troops of Pakistan were involved in operation backing the Kashmiri freedom fighters to initiate battel in the Indian held Jammu and Kashmir (Khan, 2016).

General Pervaiz Musharraf contended in his book 'In the line of Fire' that the Prime Minister had been briefed on Kargil Operation on February 5, 1999 during a visit to Neelum Valley. However, Sartaj Aziz, who was present in this visit negates any such briefing claiming that there was no mention of Kargil sector (Aziz, 2009). He further claims that when the initial clashes of $7^{\text {th }}$ May 1999 were reported in local and international media, General Musharraf and his team called a briefing session for the government on May 17, 1999 about Kashmir, in general, and Kargil, in particular. The government was informed that in response to the reports of intensified movement of Indian troops, the paramilitary forces had occupied some Indian posts across the LoC in March 1999. The remarks of prime minister to this adventure were not objectionable. However, he raised concerns about the reaction of Indian troops and its intensity. General Aziz Khan responded that there will be no retaliation. ${ }^{4}$ Sartaj Aziz and Majeed Malik (cabinet ministers) asked questions about the plan and expressed their concerns about possibility of Indian counter measures. The Army Commanders and even General Pervaiz Musharraf were of the view that India will not initiate war across the international borders. They further assured that the situation in Kashmir will be in control even if a massive war happens between the two countries (Aziz, 2009).

At the end of this discussion, Nawaz Sharif gave an impression that it was purely a military matter. Therefore, the Generals thought that the prime minister left the matter to 'the military to decide.' By then, the prime minister was fully in loop, and Lt. General Mahmood Ahmed regularly updated him about the developments in Kargil. No doubt, Nawaz Sharif had full authority to stop the operation, had he intended to do so, however, he did not raise any objection (Nawaz, 2008). It is a fact that the plan had been kept secret even from the military commanders except, General Pervaiz Musharraf, General Mahmood Ahmad, General Aziz Khan and General Tauqir Zia. The Prime Minister was not approached until the plan was exposed in 
international media. General Pervaiz Musharraf assumed it will bring India to the negotiation table. However, he didn't expect that it will be expanded by Indian military on such a large scale (Qadir, 2002). When Nawaz Sharif asked General Pervaiz Musharraf about the heavy losses of 2700 troops in the Operation (greater than those of 1965 and 1971 wars collectively), his response was that he had not anticipated such retaliation from India (Aziz, 2009). Nevertheless, this event badly exposed the professional capabilities of the military generals working on planning and implementation of this operation. No doubt, General Pervaiz Musharraf has been responsible for this ill-planned operation and should have resigned after its failure (Shah, 2016).

Nonetheless, India and Pakistan have been engaged in territorial conflicts such as control over Siachen, Sir Creeck, and Jammu \& Kashmir. Due to these issues both countries had been involved in proxy and active wars and even SAARC had not been effective in resolving the issue. However, the conflict of Kargil became severe to an extent where an all-out war was expected on the international borders between the two nuclear armed countries (Idrees, Naazer \& Rehman, 2017). Since Pakistan had denied the presence of regular troops in the operations it was also losing its position on the diplomatic front. Nawaz Sharif requested the United States to interfere for resolving the issue. He was analysing the gravity of the situation, damages on the part of Pakistan military and pressure from the United States. Therefore, Nawaz Sharif decided to unilaterally withdraw the troops engaged across the LOC back to Pakistani territory (Adnan, 2015; Waraich, 2006).

Sartaj Aziz claims that it was General Pervaiz Musharraf's plea, due to which Nawaz Sharif made a telephone call to President Clinton asking him for an early meeting. Before leaving for Washington, a meeting was arranged two hours prior to departure with three services chiefs. General Pervaiz Musharraf was much quitter and did not contradict the reports presented in this meeting about the real situation on the ground. He also agreed that Pakistan should accept the restoration of the LoC in case President Clinton would be willing to take personal interest to resolve the issue of Kashmir (Aziz, 2009). However, President Clinton affirmed his commitment to intervene with Indians for resolving Kashmir only if Pakistan will withdraw troops from across the LOC. A draft statement was finalised, and Nawaz Sharif signed an accord for this purpose with Bill Clinton on $4^{\text {th }}$ July 1999 (Adnan, 2015). The people, in general, assumed that the prime minister has taken the decision under the pressure of the United States (Kux, 2001). According to Bruce Riedel, Director of Near East and South Asia in the US NSC, Pakistan had requested for arranging Nawaz Sharif's visit. However, there was a demand of United States to withdraw troops unilaterally, prior to the meeting with President Bill Clinton (Riedel, 2002).

After signing agreement, Nawaz Sharif had to face severe criticism both by the military and the public (Adnan, 2015). Several groups in the country also criticised the military for launching an ill-fated military adventure (The Newsline, July, 1999). However, according to Nawaz Sharif, half of the posts were re-occupied by Indian troops on their side of LOC. Therefore, by signing the Washington Accord, he had saved the military from a larger debacle (Aziz, 2009). The international pressure had also mounted on the prime minister that is why he approved a plan which brought disastrous consequences for the civilian government. Nonetheless, the facts about the national security in Pakistan had never been shared with the masses. Therefore, common people misunderstood the crisis thus blaming Nawaz Sharif to have done mistake by signing agreement. In the view of commoners, the military was heading 
towards a victory in the battleground, but the political leadership lost the war on the negotiation table (Daily Dawn, August 14, 1999).

The opposition also criticised Nawaz Sharif to have given away politically, what achievements the military had done in this operation. The opposition, along with other disgruntled allies having discarded by civilian government gathered supporters for a large rally. They accused Nawaz Sharif government of isolating and humiliating Pakistan on the Kargil operation. It was considered that due to Nawaz Sharif's self-centred and ill-conceived policies, the country was completely isolated in international community and even its trusted friends like China did not support Pakistan (Daily Jang, August 5, 1999). The religious political parties like Jamaat-iIslami declared it against the interests of Kashmiri Mujahideen. Declaring it as the only solution to the issue of Kashmir, they argued that Pakistan should have openly supported the freedom movement (Haqqani, 2005). They launched a strong protest for removal of Nawaz Sharif, claiming that withdrawal of the troops from Kargil was a betrayal by the civilian government (Washington Post, September 2, 1999).

The military was also not happy and according to the military commanders, the prime minister had taken it without consulting the armed forces (Rizvi, 2003). Before his departure to Washington, Nawaz Sharif was seen off at the airport by General Pervaiz Musharraf. A TV footage also showed a friendly gesture and an understanding between the civilian government and the military. It could have been an effort of the prime minister for avoiding any allegations in future by the military that the former had taken the decision without consultation with the later. However, the military, doing so, was successful to keep itself aloof from the decision and the situation went against Nawaz Sharif (Haqqani, 2005). Moreover, the mutual understanding can be confirmed in the light of the Army Chief's later statement that Nawaz Sharif had discussed the matter with him prior to the decision (Musharraf, 2006). General Pervaiz Musharraf is reported to have given a briefing to Nawaz Sharif on the situation thus leaving the decision to be taken by the latter. To the Army Chief, "whether to withdraw or not is a political decision and I am afraid you will have to take that decision" (Nawaz, 2008). It appears that Army Chief allowed the prime minister to seek support of Washington to arrange a ceasefire and withdrawal from the front. However, he would have been in a strong position, had he opposed the withdrawal of the military from Kargil, which unfortunately he could not.

Moreover, by leaving the political decision to the prime minister, General Pervaiz Musharraf was not ready to take the responsibility. The Army Chief shifted the entire blame to the premier of which, Nawaz Sharif, being head of the government, could not escape. The situation provided Nawaz Sharif an opportunity to refute from the responsibility and disclose that military had started the operation without the consent of the government. However, it was also humiliating for a prime minister that the state institutions were not under his control (Qadir, 2002). Therefore, Nawaz Sharif was not able to oppose the Army Chief publicly and could not ask the subordinate institutions to work within their limits. This expediency initiated by the military caused Nawaz Sharif's removal from his office. Nawaz Sharif should have exposed the ill-planned and a miscalculated operation of the Army Chief and had removed him two or three weeks after the Kargil Operation. Doing so, he could have saved his government from the dismissal. In the initial days, there would have been no resistance to removal of General Musharraf even from within the military. This is because Army Chief had not taken all the army commanders and the services chiefs into confidence before launching this expediency. However, such action of the prime minister would have also weakened Pakistani position on 
Kargil operation. It would have led to confirming the Indian view of the situation thus resulting in a bad name for the entire military institution (Aziz, 2009).

\subsection{Removal of Army Chief and Military's Retaliation}

The tensions were increased between Nawaz Sharif and the Army Chief as the PML (N) supporters blamed the latter responsible for the Kargil issue. The Kargil issue thus proved to be the cause of tension and the relations between Nawaz Sharif and General Pervaiz Musharraf never normalized. The premier had sent Shahbaz Sharif, Chief Minister Punjab, as a follow-up of Washington Accord to the United States on September 14-20, 1999. In fact, Nawaz Sharif was under the fear of a military intervention and wanted assurance from the United States administration for support to the continuity of his elected government in the face of mounting pressure from the military (Nawaz, 2008). The US State Department condemned the highhandedness against anti-government demonstrations, giving a warning against any effort to derail the government (Kux, 2001). BBC commented on the statement that it does not rule out a change of government by the military (Aziz, 2009). Though, the statement might have added confidence to the Prime Minister, it could not block General Pervaiz Musharraf for more than two months to take over the government.

General Pervaiz Musharraf wanted to hold the position of Chairman JCSC along with his post as Army Chief. No doubt, this time, the Chief of Naval Staff Admiral Fasih Bokhari was supposed to takeover this post. The Admiral gave resignation six days after the confirmation of General Pervaiz Musharraf as Chairman JCSC and a week before the military coup of October 12, 1999. In fact, he had some information that the Army Chief had decided to dismiss the civilian government. However, it was a clear violation to the oath taken for loyalty to the nation and instead of informing the president, he opted to resign (Cloughley, 2008). Nawaz Sharif, initially, did not agree with the desire of General Pervaiz Musharraf, however, later, he appointed him as the Chairman JCSC (Daily Dawn, September 30, 1999). Previously, only General Jahangir Karamat had held the two offices of the Army Chief and Chairman JCSC simultaneously (Cloughley, 2008). General Pervaiz Musharraf was also made the Strategic Commander of Pakistan's Nuclear Force. Holding these positions by a person like Army Chief further strengthened his already powerful position. This decision was also in violation of the principle of sharing the responsibilities by the three services chiefs in the form of the office of JCSC. The position of chairman was to be held by the three services chiefs, one after another. However, the demand of General Pervaiz Musharraf for holding both the offices deprived the Chief of Naval Staff of his due right.

The popularity of civilian government had already been declining due to the heavy dependence on the military to improve administration and economic conditions of the country. This strategy had served his purpose temporarily but had completely diminished credibility of civilian government in future (Nizami, 2009). It proved detrimental and increased interference of the military in the civilian affairs. It also resulted in losing control of the government over to the military which was now heading some of the civilian departments directly. However, the civil society had shown reservation over Nawaz Sharif's accumulation of all powers through constitutional amendments by the parliament (Ziring, 2004). By appointing General Pervaiz Musharraf as Chairman JCSC, Nawaz Sharif wanted to assure him of no intention for his removal, so that any possible military coup could be avoided. However, a day after his appointment as Chairman JCSC, General Musharraf issued a press release that no deal has been 
made with the government for this elevation. He further added that it cannot be analysed whether the decision of the elected government will give greater stability to the politics in Pakistan (Aziz, 2009).

In August 1999, General Musharraf had visited all formation and corps commanders' headquarters to obtain their support for a counter coup in case any action is taken by government against him. General Musharraf also admitted to had convinced his colleagues that after the forced resignation of General Jahangir Karamat, this time, the military would not allow any humiliation if the prime minister would take any action against him. However, the agreement was that the military would react only to any move of government and that it will never act unilaterally. Another unhealthy event occurred, when General Pervaiz Musharraf called an explanation from Lt. General Tariq Parvez, Corps Commander Quetta and brother of Federal Minister Raja Nadir Parvez for meeting with the prime minister (Daily Dawn, October 8, 1999, 1999). General Tariq Pervaiz was forcefully kept out of loop in military affairs by General Pervaiz Musharraf because he had questioned the unilateral decision of Army Chief regarding Kargil Operation. He was transferred to GHQ in Rawalpindi, instead, he resigned in protest. Three days later, when General Pervaiz Musharraf had left for his visit to Sri Lanka, General Tariq Parvez issued a statement to the newspapers that he did not meet prime minister and had not resigned rather he was forcefully retired (Aziz, 2009).

In fact, it was this incident which further strengthened the commitment of Nawaz Sharif and attempted to replace General Pervaiz Musharraf with Lt. General Ziauddin, DG ISI (Daily Dawn, October 13, 1999). The Army Commanders, while reacting to this action of Nawaz Sharif, initiated a military coup by taking the Prime Minister House in control successfully. Thus, Nawaz Sharif was taken in custody along with the newly appointed Army Chief. The Army also took control of Karachi Airport; and despite the orders of civilian government not to allow, the pilot landed the plane at Karachi airport. However, Nawaz Sharif claimed that by that time he was arrested and somebody else might have given the orders (Waraich, 2006). In fact, Nawaz Sharif was not aware, but the army commanders had already developed a plan called 'Solidarity Operation.' It was to be launched as a counter coup in case General Pervaiz Musharraf was removed by Nawaz Sharif (Aziz, 2009).

Nawaz Sharif had been underestimating the powers of the army commanders that in the absence of the Army Chief, they would be abiding by the orders of the prime minister. Moreover, he took all measures to replace General Pervaiz Musharraf without taking other generals into confidence. The military was not happy with the resignation of former Army Chief General Jahangir Karamat. Their reservations also included Nawaz Sharif's intentions for obtaining complete control of the state power including through Thirteenth Constitutional Amendment. The Indian Prime Minister's successful visit to Pakistan, signing of the Lahore Declaration had led the military to speculate that by consolidating his ties with India, Nawaz Sharif was trying to offset the influence of the military. Therefore, the military commanders in their view found enough reasons to strike a military coup.

Moreover, General Pervaiz Musharraf was also compelled to overthrow the elected government in response to Nawaz Sharif's second move against the leadership of powerful military. The military commanders stood by his side showing loyalty to their Chief and refused to accept appointment of Ziauddin as army chief (Ziring, 2004). Though General Ziauddin was the senior most after General Pervaiz Musharraf, but it proves that the forces respect skills not 
'the genes or brotherhood' only (Sehri, 2012). However, the pace of military intervention proves that it was not a retaliation and planning was already undergoing against the civilian government. In fact, Brigadier Salahuddin Satti, the Commander of 111 Brigade in Rawalpindi Corps had conducted a secret exercise in September 1999 to identify the locations which had to be occupied during the military coup. The targets were assigned to the officers of his brigade in advance who were ready to act quickly (Aziz, 2009).

\section{Conclusion}

Appointment of the Army Chief in Pakistan has always been a discretion of civilian head of the government under the Constitution. Moreover, appointment of a junior in the list of Lt. Generals like Ziaul Haq had also been accepted by the military in 1976. However, this time the military commanders who led the military intervention were the planners of Kargil Operation. Moreover, army commanders who were apprehensive of the forced removal of Army Chief General Jahangir Karamat were not willing to allow the prime minister for repeating the action once again and establish a precedent. Other commanders who, though reluctant to stage a military coup, were compelled to follow the orders. It was mainly because of the reliving of General Tariq Parvez, Corps Commander Quetta of his duties, they had received the message to be loyal to the Army Chief. However, General Pervaiz Musharraf had become the manifestation of all-powerful position of the Army Chief.

It was clear that had the civilian government investigated the Kargil issue, General Pervaiz Musharraf and his close aides involved in Kargil episode would have been in trouble. Not doing so, the situation further exposed the weak role of civilian leaders in Pakistan's politics. It was confirmed that the Army Chief had already planned to block such efforts by the elected government. He had appointed his close aides on key positions being important for the imposition of military coup. The role of these generals was more prominent in resisting the dismissal of Army Chief by the prime minister. They wanted to save themselves from accountability and their institution form the interference of civilian government. The civilian elected leader who had saved the country from an all-out-war with India was thus deposed by the person being responsible for an ill-planned and badly executed military operation in Kashmir. The military general, who had severely damaged the cause of Kashmir became a legitimate ruler of Pakistan for nine years.

\section{References}

Adnan, M. (2015). The Kargil Crisis 1999 and Pakistan's Constraints. Journal of Political Studies, 22(1), 129-151.

Afridi, A. L. (2016). Interview for PhD Thesis with Adv. Abdul Latif Afridi by A. U. Rehman.

Aziz, S. (2009). Between Dreams and Realities: Some Milestones in Pakistan's History. Karachi: Oxford University Press.

Brooker, P. (2000). Non-Democratic Regimes: Theory, Government and Politics. New York: St. Martin's Press.

Cloughley, B. (2008). War, Coups and Terror: Pakistan Army in the Year of Turmoil. South Yorkshire: Pen \& Sword Books Ltd.

Daily Dawn, November 21, 1998. Pakistan Armed Forces Ordinance (Acting in Aid to the Civil Powers) 1998. Pakistan Armed Forces. Islamabad. 
Daily Dawn, February 17, 1999. Islamabad.

Daily Dawn, February 21, 1999. Text of Lahore Declaration. Islamabad.

Daily Dawn, February 22, 1999. Islamabad.

Daily Dawn, August 14, 1999. Islamabad.

Daily Dawn, September 30, 1999. Islamabad.

Daily Dawn, October 8, 1999. Islamabad.

Daily Dawn, October 13, 1999. Islamabad.

Daily Jang, August 5, 1999. Islamabad.

Finer, S. E. (1975). The Man on the Horse Back: The Role of Military in Politics (2 ${ }^{\text {nd }}$ ed.). Middlesex: Penguin Books.

Haqqani, H. (2005). Pakistan: Between Mosque and the Military. Lahore: Vanguards.

Huntington, S. P. (1968). Political Order in Changing Societies. New Haven: Yale University Press.

Idrees, M., Naazer, M. A., \& Rehman, A. U. (2017). Conflicts and conflict management in SAARC. Liberal Arts and Social Sciences International Journal 1(2), 1-11.

Janowitz, M. (1977). Military Institutions and Coercion in the Developing Nations. Chicago: University of Chicago Press.

Karamat, J. (1998, October 06). Speach of Army Chief General Jahangir Karamat on 5th October 1988 at Naval Staff College. Islamabad: Daily Dawn.

Khan, M. A. (2016). Interview with Air Marshal (Rtd.) M. Asghar Khan for PhD Dissertation by A. U. Rehman.

Khan, N. U., \& Rehman, A. U. (2018). National character and leadership in Pakistan: challenges and response. Pakistan Journal of Criminology 10(2), 57-71.

Kux, D. (2001). The United States and Pakistan, 1947-2000: Disenchanted Allies. Karachi: Oxford University Press.

Musharraf, P. (2006). In the Line of Fire: A Memoir. London: Simon \& Schuster UK Ltd.

Nawaz, S. (2008). Crossed Swords: Pakistan: Its Army, and the Wars Within. Karachi: Oxford University Press.

Nizami, Q. (2009). Jernail aur Siasatdan Awam ki Addalat Main (Generals and Politicians in the Court of History) [Urdu]. Lahore: Jahangir Books.

Nordlinger, E. A. (1977). Soldiers in Politics: Military Coups and Governments. Englewood Cliffs: Prentice Hall Inc.

Qadir, S. (2002). An Analysis of Kargil Conflict 1999. RUSI Journal, 1-24.

Rehman, A. U., Khan, A., \& Khan, B. (2017). Governemnt-opposition relations during Benazir Bhutto's Rule. Liberal Arts and Social Sciences International Journal (LASSIJ), 1(2), 24-33.

Riedel, B. (2002). American Diplomacy and the 1999 Kargil Summit at Blair House. Philadelphia: Centre for Study of India at the University of Pennsylvania.

Rizvi, H. A. (1999). Pakistan in 1998: The Polity under Pressure. Asian Survey, 39, 177-184.

Sehri, I. R. (2012). Judges and Generals in Pakistan: Volume-I . Guildford, Surrey: Grosvenor House Publishing.

Shah, M. (2016). Interview for PhD Thesis with Brigadier (Rtd.) Mahmood Shah by A. U. Rehman.

The Newsline, July, 1999. Karachi.

Waraich, S. (2006). Who is the Traitor? (Who is Traitor) [Urdu]. Lahore: Sagar Publications. Washington Post, September 2, 1999.

Ziring, L. (2004). Pakistan: At the Cross Currents of History. Lahore: Vanguards. 


\section{Notes:}

${ }^{1}$ General Jahangir Karamat, while addressing at the Naval Staff College, criticised the policies of elected government thus showing concern over the political instability mainly the worsening ethnic and sectarian violence, anti-opposition measures of the civilian government and grievances of the smaller provinces. The Army Chief was also concerned over the worsening economic situation which was dangerous for the corporate interests of the military (Karamat, 1998).

${ }^{2}$ General Pervaiz Musharraf was appointed as Army Chief on $6^{\text {th }}$ October 1998 by superseding the senior most, Lt. General Ali Kuli Khan and number second, Lt. General Nawaz Khan (Nawaz, 2008).

${ }^{3}$ Adv. Abdul Latif Afridi quotes Rana Naveed (PML-N), that a suggestion was given to Nawaz Sharif in a meeting for appointment of General Ali Kuli Khan as Army Chief. But he said, "over my dead body," because he was the brain of General Abdul Waheed Kakar and was a key player in his removal during first term as Prime Minister (Afridi, 2016).

${ }^{4}$ Ideologically, he was from Jamat-i-Islami and belonged to Kashmir (Afridi, 2016). 